\title{
Laboratory Certification Document
}

National Cancer Institute

\section{Source}

National Cancer Institute. Laboratory Certification Document. NCI Thesaurus. Code C115712.

Official records indicating the competence of a laboratory to participate in a given clinical trial. 